\title{
Characterization of Soiling Bands on the Bottom Edges of PV Modules
}

\author{
Yong-Qin Cui', Jian-Hua Xiao ${ }^{2 *}$, Jin-Li Xiang ${ }^{1}$ and Jia-Huan Sun ${ }^{2}$ \\ ${ }^{1}$ College of Resources and Environment, Shanxi University of Finance and Economics, Taiyuan, China, ${ }^{2}$ Northwest Institute \\ of Eco-Environment and Resources, Chinese Academy of Sciences, Lanzhou, China
}

Soiling of photovoltaic (PV) modules, especially non-uniform soiling, can lead to PV power loss. For example, soiling bands at the bottom edge of framed modules are caused by the accumulation of water and dirt at a lower tilt angle. However, few studies have investigated this issue. In this study, industrial and commercial metal rooftop PV power stations in central and eastern China were investigated, with a focus in Xi'an and Kaifeng cities. The results show that (1) soiling bands were widespread, even in Guangzhou city, where annual rainfall is approximately $1,800 \mathrm{~mm}$; (2) soiling bands were found during every month in Xi'an city, even from July to September when heavy rainfall occurs frequently; (3) three types of soiling bands were observed on modules

OPEN ACCESS

Edited by:

Enrico Maria Vitucci,

University of Bologna, Italy

Reviewed by:

Karthick Alagar,

KPR Institute of Engineering and Technology, India Runsheng Tang,

Yunnan Normal University, China

*Correspondence:

Jian-Hua Xiao xiaojh@/zb.ac.cn

Specialty section: This article was submitted to Solar Energy, a section of the journal Frontiers in Energy Research

Received: 08 February 2021 Accepted: 22 March 2021 Published: 09 April 2021

Citation:

Cui $Y-Q$, Xiao J-H, Xiang J-L and Sun J-H (2021) Characterization of Soiling Bands on the Bottom

Edges of PV Modules.

Front. Energy Res. 9:665411. doi: 10.3389/fenrg.2021.665411 (rectangular, transverse trapezoidal, and triangular), with double triangular, arch, and shallow U-shape types also being observed in landscape-oriented modules; (4) the mean relative difference of the maximum direct current due to soiling bands between one maximum power point tracking system and its control from June 19 to October 2, 2019 in Kaifeng city was approximately 4.7\%.

Keywords: photovoltaic, non-uniform soiling, soiling band, bottom edge, lower tilt angle

\section{INTRODUCTION}

The accumulation of dust, dirt, and other contaminants on photovoltaic (PV) modules is an important environmental factor that reduces energy generation from PV power plants (Gostein et al., 2014; Klugmann-Radziemska, 2020), especially in arid and semi-arid areas (Kimber et al., 2006; Sayyah et al., 2014; Cordero et al., 2018; Dahlioui et al., 2019). Factors influencing the settlement of contaminants, the effect of soiling on PV system performance, and relevant mitigation methods have been studied for many years (Mani and Pillai, 2010; Sarver et al., 2013; Suellen et al., 2016; Jamil et al., 2017; Said et al., 2018). However, previous research has focused on the effect of uniform soiling distributions on PV power stations installed at a high tilt angle, with few studies on the effect of non-uniform soiling distribution, especially at a lower tilt angle. This is because the tilt angle is designed to be similar to the latitudinal angle of the PV system in order to receive maximum PV energy (Cano et al., 2014), and very few studies have been performed near the equator. Another reason is that utility-scale PV power plants distributed on the metal roofs of industrial and commercial buildings have previously been very rare before 2016 in China. According to the author's investigation in China, the tilt angle of the metal roof is typically $2-3^{\circ}$ and the PV modules lie flat on the roof.

Studies show that the effect of non-uniform soiling on PV energy generation is proportionally greater than that of uniform soiling (Schill et al., 2015; Maghami et al., 2016; Molin, 2018). This is 
because the PV cells in the modules are connected in a series and the cell with the heaviest soiling will regulate the current flowing through the PV module (John, 2015). Soiling tends to primarily accumulate at the bottom of the PV modules and sometimes at the top (Lorenzo et al., 2013; Qasem et al., 2014), owing to wind or rain transport. In this study, soiling at the top or sides of modules is neglected because it is relatively rare, as observed in the field investigation. Conversely, bottomedge soiling is widely distributed in PV stations with a low tilt angle, especially on the metal roofs of industrial and commercial buildings, and even on the PV carport with a low tilt angle. PV stations on the metal roofs of industrial and commercial buildings is one kind of building applied/attached PV (BAPV), which indicates the PV system is added/attached or applied to a building, while PV carport is one kind of building integrated PV (BIPV), which illustrates the concept of replacing the traditional building envelop, such as window, wall, roof by PV (Reddy et al., 2020). Both of them, especially BIPV, have been focused by researchers in recent times (Karthick et al., 2018, 2020; Pichandi et al., 2020; Ramanan et al., 2020).

Soiling at the module bottom edge not only affects the free space between the solar cells and frame but also the solar cell surface, which significantly influences the performance of PV installations (Lorenzo et al., 2013). For example, bottom-edge soiling of $0.5 \%$ of the total area of a module, covering $\sim 25 \%$ of the bottom right corner cell and $\sim 9 \%$ of its neighbor, resulted, at peak, in a $9 \%$ power loss with a tilt angle of approximately $5^{\circ}$ at a pre-construction site-survey station in the southwest US. Furthermore, the module was only cleaned by a $>5 \mathrm{~mm}$ rainfall event (Gostein et al., 2015). In another study, an energy yield loss of up to $10-20 \%$ was observed for PV cells owing to soiling bands on the edge of framed cells (Ibrahim, 2011). For PV cells in a landscape (long edge down) configuration, a 20-26.7\% power loss was observed due to $5-10 \mathrm{~cm}$ soiling bands on the bottom edge of modules with a tilt angle of approximately $3^{\circ}$ at a rooftop PV power station in Shanxi, China (Yan and Yao, 2018). Meanwhile, Ilse et al. reported that the shading of only $50 \%$ of a single solar cell due to dust accumulation can trigger the bypass diode of one string, which can reduce the power production of a typical three-string module by one third, and may even cause complete power loss if the bottom rows of cells are fully covered (Ilse et al., 2019).

Therefore, it is important to investigate soiling bands at the bottom edge of PV modules. However, presently, there are no systematic studies on the distribution characteristics, formation mechanisms, shape characteristics, effects on modules, and effective removal methods of PV-soiling bands. While conducting other research on PV modules, the authors of this study happened to find a wide distribution of bottom-edge soiled PV modules at commercial metal rooftop PV power stations in several parts of central and eastern China (especially Xi'an city). Photographs of soiling bands were captured and exhibited their unwanted characteristics, such as hotspots and hazy appearances. As a nonsystematic paper, the authors hope to attract more scholars and owners of PV power stations to pay attention to the adverse effect of soiling bands, and to encourage its systemic study for finding a reliable and low-cost solution.

\section{FORMATION OF SOILING BANDS}

For modules with a frame, soiling is particularly likely to accumulate at the bottom edge, especially at lower tilt angles (Gostein et al., 2013; Molin, 2018). This is because the frame typically extends approximately 1-3 $\mathrm{mm}$ above the front glass, enabling water, dust, and dirt to easily accumulate at the bottom of the module (Pedersen et al., 2016). Under the driving force of gravity, small amounts of precipitation, snow, dew, frost, or cleaning water are typically insufficient to move the dust particles up the frame and carry them to the bottom of the PV module, which directly leads to the formation of a stagnant area at the bottom edge (John, 2015). Particle-laden runoff then flows to the stagnant area, and when the speed of runoff decreases to zero, most of the particles sink to the bottom of the stagnant area. In the field investigation, the authors in this study found that once a stagnant area exists, it is difficult to clean the stagnant area through natural causes, including moderate rainfall; this is because the strength of the raindrops is weakened by the upper surface of the stagnant area, water exhibits a good buffer effect, and raindrops have little effect on particles deposited at the bottom of the stagnant area. After evaporation of the stagnant water, a soiling band is formed, the shape of which is similar to that of the original stagnant water pool.

\section{REGIONAL AND SEASONAL DISTRIBUTION OF SOILING BANDS}

Due to the buffer role of the stagnant water, soiling deposited at the bottom of the module does not flow away with rainfall, but becomes increasingly thick with increased rainfall during seasons with light to moderate rainfall, such as autumn, winter, and spring in northern China. In serious cases, the color of the module cell is not visible over the entire area covered by the soiling band.

In this study, photographs of industrial and commercial metal rooftop PV power stations were collected in several provinces in central and eastern parts of China from 2018 to 2020, as shown in Figure 1, where soiling bands were widely observed. Even at Guangzhou city in Guangdong province, where the average annual rainfall is approximately $1,800 \mathrm{~mm}$, soiling bands were observed due to less frequent heavy rainfall in the dry season lasting from late October to March with generally cool and dry weather (Chen et al., 2012).

We also collected photographs from May 2018 to June 2020 of a $\mathrm{PV}$ power station installed on an industrial and commercial metal rooftop in Xi'an, Shaanxi province (photographs from August and October 2018 and January 2020 were missing), as shown in Figure 2. The tilt angle of this PV power station is approximately $3^{\circ}$. Soiling bands were observed at this power station during every month of the year. July and August, which experience heavy rainfall, had the smallest bands with only a thin layer of soiling. From March-June and September-November, soiling bands were severe along the lower edges, but the nonsoiling areas were relatively clean. This is primarily due to the light-moderate rainfall experienced during these months. Conversely, December-February experienced a smaller amount 

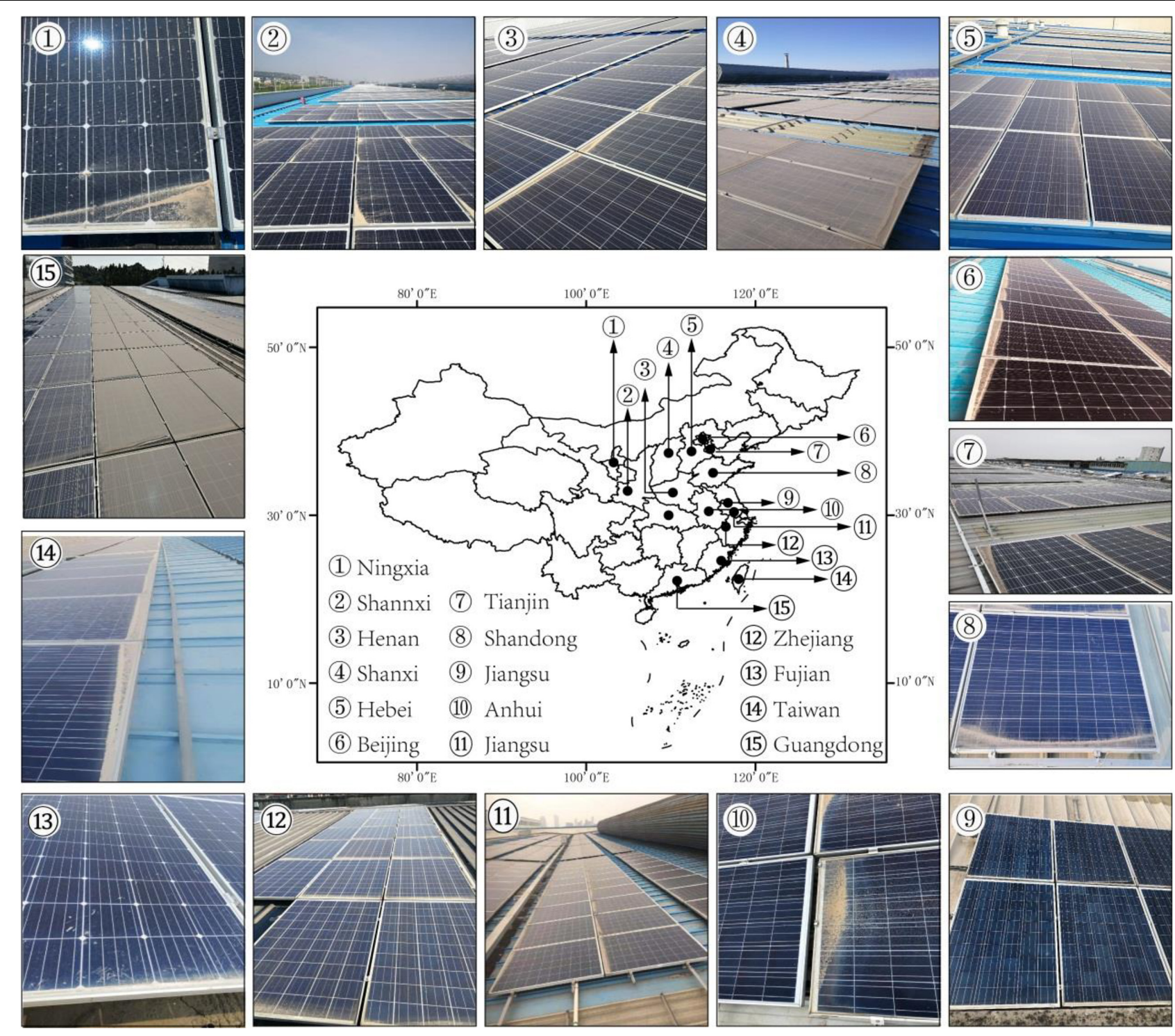

FIGURE 1| Photographs of soiling bands on industrial and commercial metal rooftop PV power stations in several provinces in central and eastern China from 2018 to 2020 .

of rainfall with a lower frequency; this, along with severe winter pollution led to thicker soiling bands, with a layer of dust covering the non-soiling area. Light and moderate rainfall cleaned only the non-soiling area, while only heavy rainfall cleaned the soiling bands. For example, as shown in Figure 2, the soiling bands disappeared in the photographs in July 2019 and May 2020, both of which were taken after a heavy rain event.

\section{SHAPES OF SOILING BANDS}

PV modules may be installed in either portrait (short edge down) or landscape (long edge down) configurations (Karthick et al., 2020). Previous field investigations conducted by the authors in this study have shown that modules in most industrial and commercial metal rooftop PV power stations with a lower tilt angle are installed in a portrait configuration, with few of them being installed in a landscape configuration at the central and eastern parts of China.

During field investigations, it was found that the shape of bottom edge soiling bands mainly depends on the tilt angle in updown and left-right directions, as well as on the deformation of the PV modules. The tilt angle in the up-down direction depends on the tilt angle of the metal rooftop and the tilt angle in the leftright direction depends on the height differences in the left and right directions that are caused by construction errors.

For the portrait configuration, the length of the shorter side of the PV module was generally $1 \mathrm{~m}$ approximately and the bracket was typically placed in the left-right direction. Therefore, deformation of the center of the shorter side was 


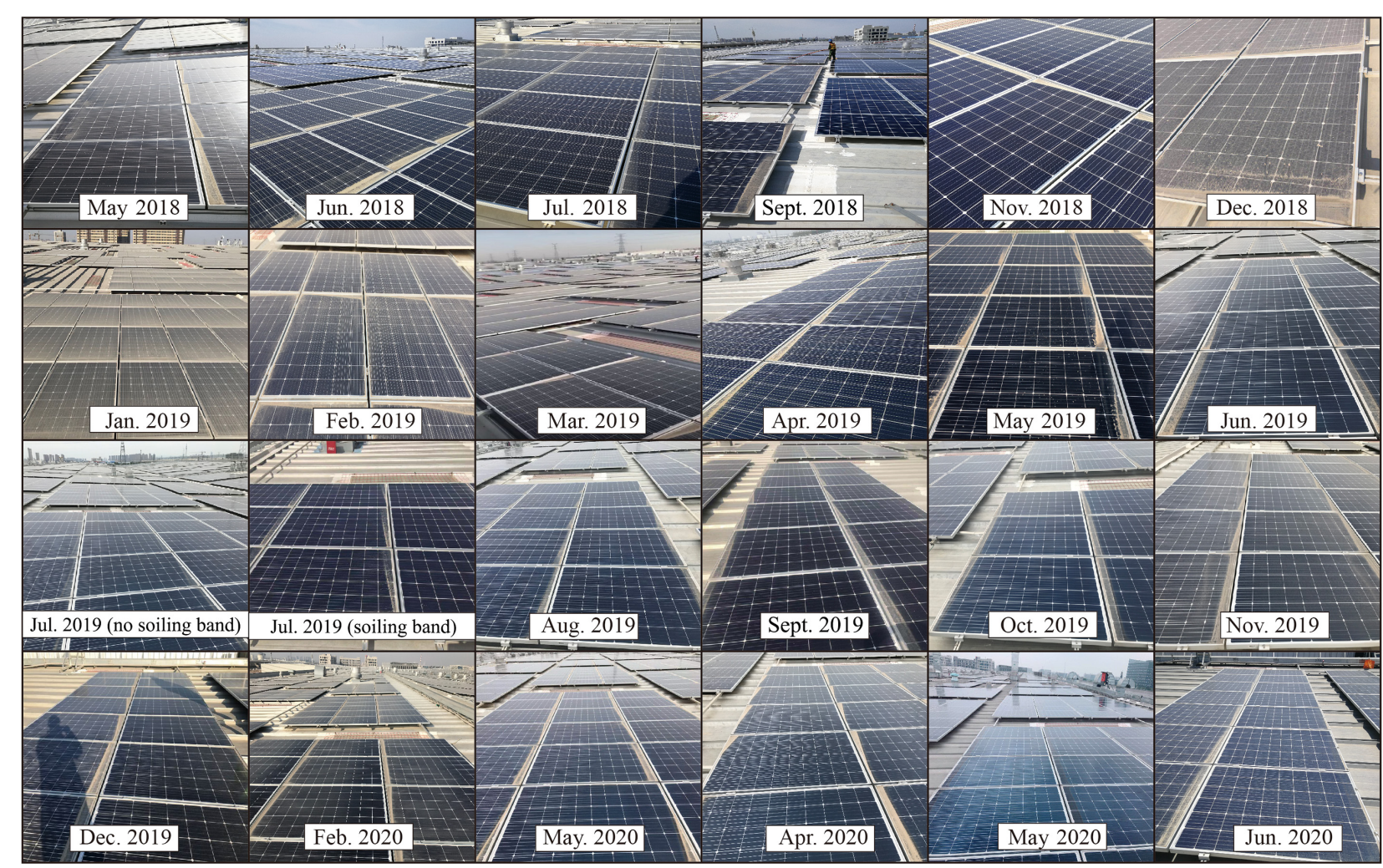

FIGURE 2 | Soiling strip photographs of an industrial and commercial metal rooftop PV power station in Xi'an city from May 2018 to June 2020.

not evident. Consequently, only three soiling band shapes were observed, namely: rectangular, transverse trapezoidal, and triangular (Figure 3). For the landscape configuration, the length of the longer side of the module was approximately $1.65-2 \mathrm{~m}$ and the bracket was typically placed in the up-down direction. Therefore, deformation of the center of the shorter edge was more evident. Consequently, more soiling band shapes were observed, in addition to those observed in portrait configuration, namely: double triangular, arch, and shallow U-shape (Figure 3).

\section{ADVERSE EFFECT OF SOILING BANDS ON THE MAXIMUM DIRECT CURRENT}

Part of the incoming radiation to PV cells covered by soiling bands is absorbed and reflected by the soiling band, thereby reducing the output of the entire module. Even if only one cell is covered fully or partially, the current flowing through the PV module will be affected due to the series connection of the cells (John, 2015).

An experiment to determine the influence of soiling bands on power generation was conducted in a PV power station installed on an industrial and commercial metal rooftop in Kaifeng city (latitude $34.8^{\circ}$ and longitude $114.3^{\circ}$ ), Henan Province, China, from June 19 to October 2, 2019. The tilt angle of this PV power station is approximately $4^{\circ}$. However, data from June 28, August 10, and August 17 were missing. One PV string inverter was selected due to its stable operation since installation. One PV string inverter comprised four maximum power point tracking systems (MPPTSs), with each MPPTS controlling three arrays in shunt connection and each array containing 20 modules in a series connection. The maximum direct current (MDC) of each MPPTS was recorded every $2 \mathrm{~min}$ and the mean MDC for 1 day was calculated by eliminating the zero values. MPPTS one and MPPTS two were chosen for testing as they were distributed adjacent to each other and exhibited the minimum difference according to data collected prior to the experiment between May 25 and June 18, 2019 (Figure 4). MPPTS one refers to the experimental group with no soiling band due to manual cleaning; however, the area not covered by soiling bands was not cleaned. MPPTS two is the control group that was not cleaned. The relative differences (RD) between the daily maximum current of MPPTS one $\left(\mathrm{I}_{m c}\right)$ and MPPTS two $\left(\mathrm{I}_{m s}\right)$ were calculated by Eq. (1).

$$
R D(\%)=\left(I_{\mathrm{mc}}-I_{m s}\right) / I_{m s} \times 100
$$

Figure 4 shows that RDs gradually increased with instances of light rain or moderate rain that occurred between two thunderstorms; subsequently, these values suddenly dropped to the same range as those recorded before the experiment. This indicates that soiling bands began to form and gradually became thicker after light or moderate rain, before disappearing after thunderstorms. A maximum RD of approximately $20 \%$ was recorded on September 3 after two light rain events and one 


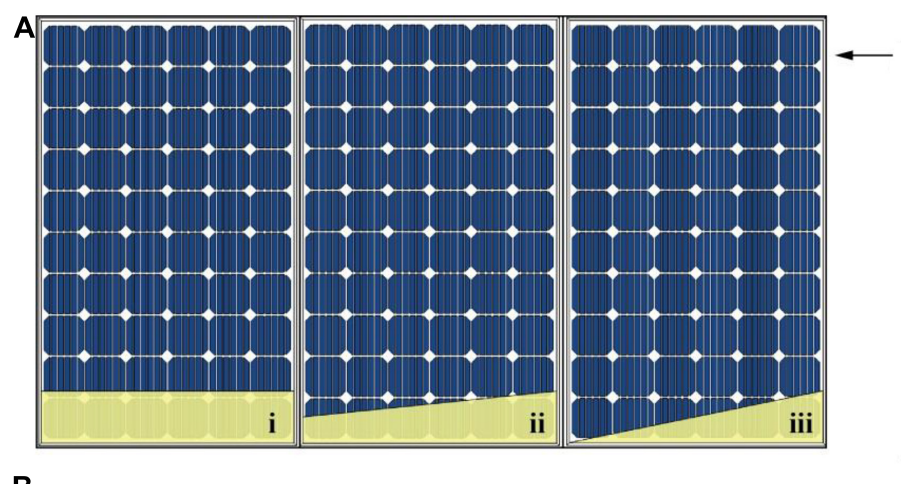

portrait
i: rectangle
ii: transverse trapezoid
iii: triangle

landscape

i: rectangle

ii: transverse trapezoid

iii: triangle

iv: double triangle

v: shallow U-shape

vi: arch

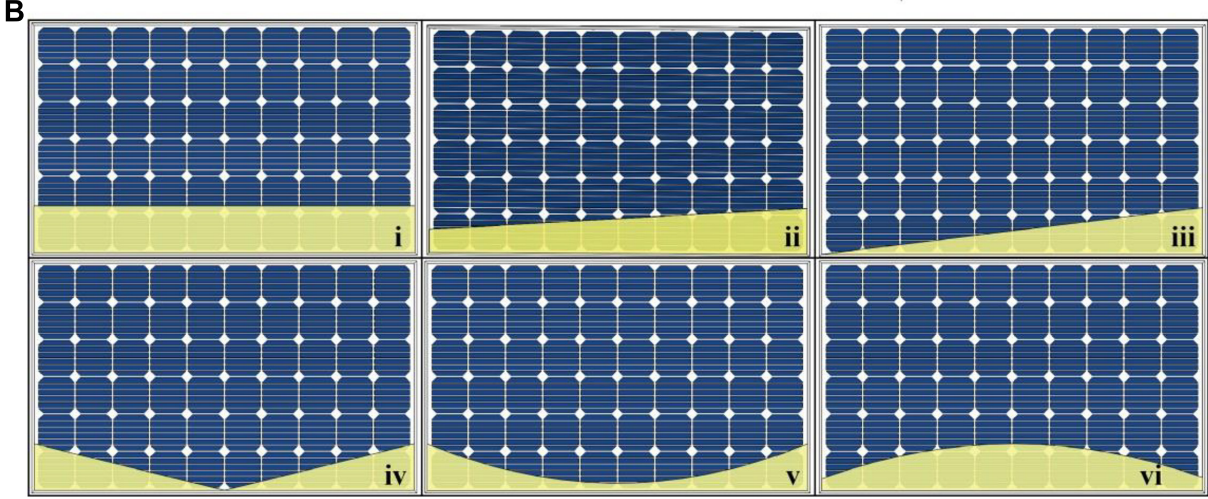

FIGURE 3 | Schematic showing the shapes of soiling bands: (A) portrait and (B) landscape configurations.

moderate rain event. RDs of $14 \%$ on July 28 and $10 \%$ on June 27 were also observed. The mean $\mathrm{I}_{m c}$ value was $8.57 \mathrm{~A}$ and the mean $\mathrm{I}_{m s}$ value was 8.19 A from June 19 to October 2, 2019, resulting in a mean $\mathrm{RD}$ of $4.7 \%$ lower than the power loss $9 \%$ in Gostein et al. (2015) and 10-20\% in Ibrahim (2011) and 2026.7\% in Yan and Yao (2018). The reason is the thunderstorms only occurring between June and September, can clean the soiling bands in Kaifeng city. That means the RD of $4.7 \%$ is smaller than that in any other months, and even the annual RD.

Furthermore, the RD did not change substantially with dramatic changes in daily irradiation, which would be indicated by dramatic changes in $\mathrm{I}_{m c}$ or $\mathrm{I}_{m s}$. Thus, RD changed only slightly between sunny and overcast days. For example, the difference in $\mathrm{I}_{m c}$ between August 22 and August 27 was approximately three times. However, the difference in RD between August 22 and August 27 was only approximately $6.5 \%$.

\section{OTHER ADVERSE EFFECTS OF SOILING BANDS}

\section{Hotspots}

Similar to the effect of partial shading, soiling bands at the bottom edges of the framed modules resulted in a non-uniform incoming radiation to the PV cell, which can lead to hotspots (Al Dowsari et al., 2014). Temperature differences of up to $23^{\circ} \mathrm{C}$ have been observed between non-covered cells and cells covered by soiling bands (Lorenzo et al., 2013). Unlike localized overheating caused by semi-homogeneous deposits, hot bands, or bird droppings (Cipriani et al., 2020), the entire area covered by soiling bands exhibits a higher temperature than other areas, which was also observed in our field investigation.

\section{Hazy Appearance}

After cleaning the soiling bands, a hazy appearance of the glass corresponding to the location of soiling bands was observed at the lower edge of the PV modules during a few months after installation at Xi'an, which is not observed on the modules covered by partial shading. This phenomenon was also examined in Sánchez-Friera et al. (2011) and is thought to be caused due to sedimentation of rainwater and an ion exchange between alkalis in the glass and $\mathrm{H}+$ ions in the water (Lombardo et al., 2005; Manganiello et al., 2015). However, the color of the hazy appearance is reminiscent of the oxidation of the antireflection layer (as shown in Figure 3 in Sánchez-Friera et al., 2011); this layer may be another reason for the hazy appearance of the lower edge of the module.

\section{Fast Aging}

Compared to the non-soiling areas of PV modules, the stagnant water corresponding to the location of the soiling bands has a longer invasion time due to the seal between the glass and the metal frame; this water can damage the seal and eventually reduce the service life of PV modules (John, 2015; Manganiello et al., 2015). 


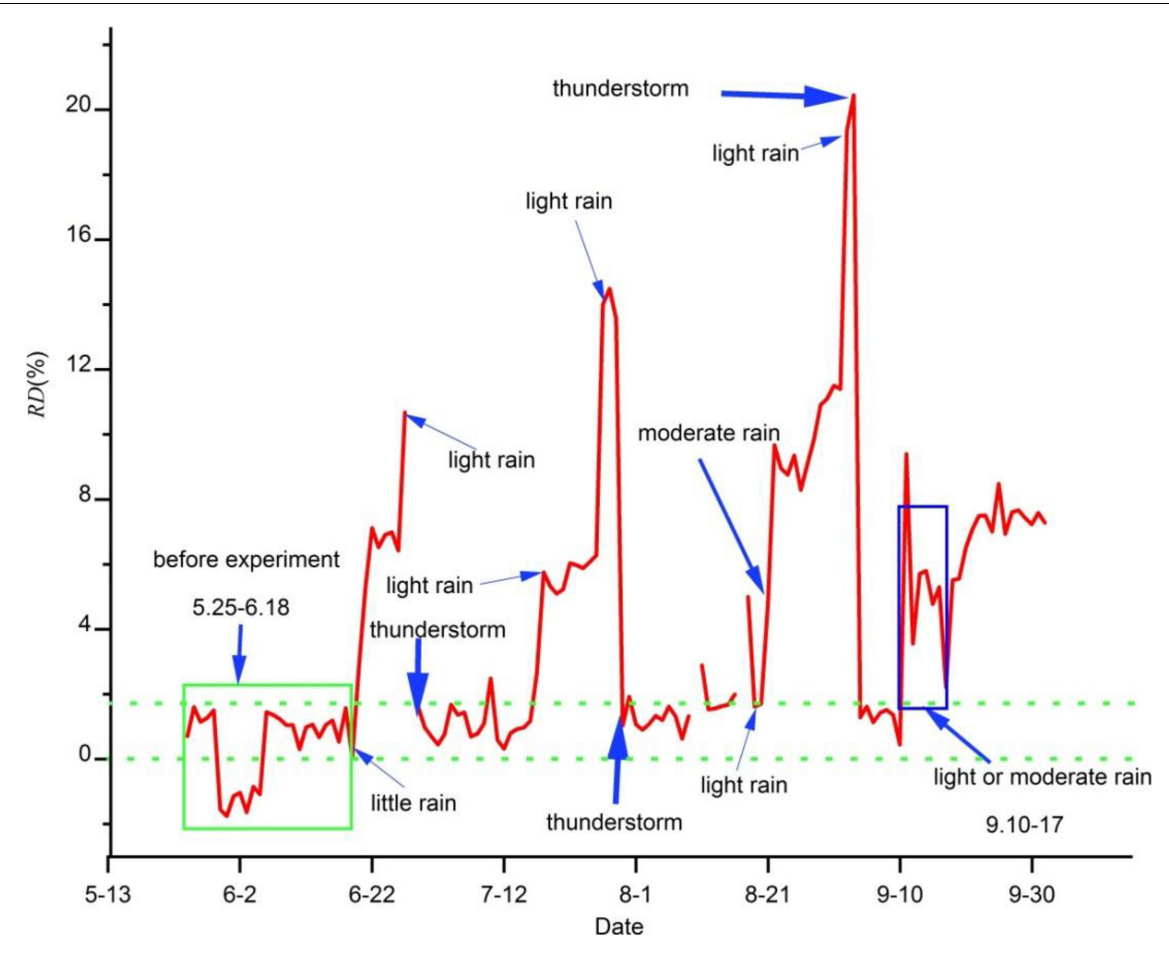

FIGURE 4 | Relative differences (RDs) between the daily maximum current of MPPT one $\left(I_{m c}\right)$ and MPPT two ( $\left.I_{m s}\right)$.

\section{CONCLUSION}

As a type of non-uniform PV soiling, soiling band development at the bottom edge of PV modules is widespread in PV stations with lower tilt angles, especially in industrial and commercial metal rooftop PV power stations such as those in central and eastern China. This study elucidated that heavy soiling bands were observed in every month with no heavy rainfall, even if the average annual rainfall reached $1,800 \mathrm{~mm}$. Even in months with heavy rainfall, thin soiling bands were found after one instance of light or moderate rainfall in Xi' an city. Moreover, the thickness of the soiling band gradually increased with instances of light or moderate rainfall, and then suddenly decreased to zero with heavy rainfall. In addition to the serious effects on the PV power output, hotspot formation, hazy module appearance, and fast aging of PV modules also resulted from the development of soiling bands. Nevertheless, more in-depth research on the adverse effects of soiling bands is required in future and should focus on:

- The relationship between the width of the soiling bands and the tilt angle;

- The influence of the width and thickness of the soiling bands on the power generation losses;

- The generation mechanism of hazy appearance and its influence on the power generation losses, and the removal methods;

- Long term observation of the influence of soiling bands on power generation losses;
- The relationship between rain intensity and precipitation and the formation and disappearance of soiling bands;

- The removal methods of the soiling bands;

- The mechanism and speed of the fast aging of modules due to the soiling bands.

\section{DATA AVAILABILITY STATEMENT}

The original contributions presented in the study are included in the article/supplementary material, further inquiries can be directed to the corresponding author/s.

\section{AUTHOR CONTRIBUTIONS}

J-HS: conceptualization and investigation. Y-QC and J-HS: data curation and validation. J-HS and J-HX: formal analysis. Y-QC, J-HS, and J-LX: methodology. Y-QC: supervision. J-HS, J-LX, and J-HX: writing-original draft. Y-QC, J-HS, J-LX, and J-HX: writing-review and editing. All authors have read and agreed to the published version of the manuscript.

\section{FUNDING}

This research was funded by the Scientific and Technological Innovation Programs of Higher Education Institutions in Shanxi (grant no. 2019L0483) and the Opening Foundation of Key Laboratory of Desert and Desertification, Chinese Academy of Sciences (grant no. KLDD-2018-007). 


\section{REFERENCES}

Al Dowsari, A., Bkayrat, R., AlZain, H., and Shahin, T. (2014). "Best practices for mitigating soiling risk on PV power plants," in Proceeding of the 2014 Saudi Arabia Smart Grid Conference (SASG), 14-17 Dec, (Jeddah), 1-6.

Cano, J., John, J. J., Tatapudi, S., and Tamizh Mani, G. (2014). "Effect of tilt angle on soiling of photovoltaic modules," in Proceeding of the 2014 IEEE 40th Pho-tovoltaic Specialist Conference (PVSC), 8-13 June, (Denver, CO), 3174-3176.

Chen, L., Peng, S., Liu, J., and Hou, Q. (2012). Dry deposition velocity of total suspended particles and meteorological influence in four locations in Guangzhou. China. J. Environ Sci. 24, 632-639. doi: 10.1016/s1001-0742(11) 60805-X

Cipriani, G., D’Amico, A., Guarino, S., Manno, D., Traverso, M., and Di Dio, V. (2020). Convolutional neural network for dust and hotspot classification in PV modules. Energies 13:6357. doi: 10.3390/en13236357

Cordero, R. R., Damiani, A., Laroze, D., MacDonell, S., Jorquera, J., Sepúlveda, E., et al. (2018). Effects of soiling on photovoltaic (PV) modules in the Atacama Desert. Sci. Rep. 8:13943. doi: 10.1038/s41598-018-32291-8

Dahlioui, D., Laarabi, B., and Barhdadi, A. (2019). Investigation of soiling impact on PV modules performance in semi-arid and hyper-arid climates in Morocco. Energy Sustain. Dev. 51, 32-39. doi: 10.1016/j.esd.2019.05.001

Gostein, M., Caron, J. R., and Littmann, B. (2014). "Measuring soiling losses at utility-scale PV power plants," in Proceeding of the 2014 IEEE 40th Photovoltaic Specialist Conference (PVSC), 8-13 June, (Denver, CO: IEEE), 0885-0890.

Gostein, M., Düster, T., and Thuman, C. (2015). "Accurately measuring PV soiling losses with soiling station employing module power measurements," in Proceedings of 42nd IEEE Photovoltaic Specialists Conference (PVSC), 14-19 June, (New Orleans, LA), 1-4.

Gostein, M., Littmann, B., Riley Caron, J., and Dunn, L. (2013). “Comparing PV power plant soiling measurements extracted from PV module irradiance and power measurements," in Proceeding of the 2013 IEEE 39th Photovoltaic Specialists Conference (PVSC), (Tampa, FL), 3004-3009.

Ibrahim, A. (2011). Effect of shadow and dust on the performance of silicon solar cell. J. Basic Appl. Sci. Res. 1, 222-230.

Ilse, K., Micheli, L., Figgis, B. W., Lange, K., Daßler, D., Hanifi, H., et al. (2019). Techno-economic assessment of soiling losses and mitigation strategies for solar power generation. Joule 3, 2303-2321. doi: 10.1016/j.joule.2019.08.019

Jamil, W. J., Abdul Rahman, H., Shaari, S., and Salam, Z. (2017). Performance degradation of photovoltaic power system: review on mitigation methods. Renew. Sust. Energ. Rev. 67(Suppl. C), 876-891. doi: 10.1016/j.rser.2016.09.072

John, J. J. (2015). Characterization of Soiling Loss on Photovoltaic Modules, and Development of a Novel Cleaning System. Doctor thesis, Department of Electrical Engineering, Indian Institute of Technology, Bombay.

Karthick, A., Kalidasa Murugavel, K., Kalaivani, L., and Saravana Babu, U. (2018). Performance study of building integrated photovoltaic modules. Adv. Build. Energ. Res. 12, 178-194. doi: 10.1080/17512549.2016.1275982

Karthick, A., Manokar Athikesavan, M., Pasupathi, M. K., Manoj Kumar, N., Chopra, S. S., and Ghosh, A. (2020). Investigation of inorganic phase change material for a semi-transparent photovoltaic (STPV) module. Energies 13:3582. doi: 10.3390/en13143582

Kimber, A., Mitchell, L., Nogradi, S., and Wenge, H. (2006). "The effect of soiling on large grid-connected photovoltaic systems in California and the southwest region of the United States," in Proceeding of the Photovoltaic Energy Conversion, Conference Record of the 2006 IEEE 4th World Conference 2, (IEEE), 2391-2395.

Klugmann-Radziemska, E. (2020). Shading, dusting and incorrect positioning of photovoltaic modules as important factors in performance reduction. Energies 13:1992. doi: $10.3390 /$ en 13081992

Lombardo, T., Ionescu, A., Lefèvre, R., Chabas, A., Ausset, P., and Cachier, H. (2005). Soiling of silica-soda-lime float glass in urban environment: measurements and modelling. Atmospheric Environ. 39, 989-997. doi: 10.1016/ j.atmosenv.2004.10.030

Lorenzo, E., Moretón, R., and Luque, I. (2013). Dust effects on PV array performance: in-field observations with non-uniform patterns. Prog. Photovol.: Res. Appl. 22, 666-670. doi: 10.1002/pip.2348
Maghami, M. R., Hizam, H., Gomes, C., Radzi, M. A., Rezadad, M. I., and Hajighorbani, S. (2016). Power loss due to soiling on solar panel: a review. Renew. Sust. Energ. Rev. 59, 1307-1316. doi: 10.1016/j.rser.2016.01.044

Manganiello, P., Balato, M., and Vitelli, M. (2015). A survey on mismatching and aging of PV modules: the closed loop. IEEE Trans. Industr. Electronics 62, 7276-7286. doi: 10.1109/tie.2015.2418731

Mani, M., and Pillai, R. (2010). Impact of dust on solar photovoltaic (PV) performance: research status, challenges and recommendations. Renew. Sust. Energ. Rev. 14, 3124-3131. doi: 10.1016/j.rser.2010. 07.065

Molin, D. (2018). Experimental Analysis of the Impact of Soiling on Photovoltaic Modules Performance. Master's thesis. Milan: Politecnico di Milano.

Pedersen, H., Strauss, J., and Selj, J. (2016). Effect of soiling on photovoltaic modules in Norway. Enrgy Proced. 92, 585-589. doi: 10.1016/j.egypro.2016.07. 023

Pichandi, R., Murugavel Kulandaivelu, K., Alagar, K., Dhevaguru, H. K., and Ganesamoorthy, S. (2020). "Performance enhancement of photovoltaic module by integrating eutectic inorganic phase change material," in Energy Sources, Part A: Recovery, Utilization, and Environmental Effects, 1-18. doi: 10.1080/ 15567036.2020.1817185

Qasem, H., Betts, T. R., Müllejans, H., AlBusairi, H., and Gottschalg, R. (2014). Dust-induced shading on photovoltaic modules. Prog. Photovol.: Res. Appl. 22, 218-226. doi: 10.1002/pip.2230

Ramanan, P., Kalidasa Murugavel, K., Karthick, A., and Sudhakar, K. (2020). Performance evaluation of building-integrated photovoltaic systems for residential buildings in southern India. Build. Ser. Eng. Res. Technol. 41, 492-506. doi: 10.1177/0143624419881740

Reddy, P., Gupta, M. V. N. S., Nundy, S., Karthick, A., and Ghosh, A. (2020). Status of BIPV and BAPV system for less energy-hungry building in India-a review. Appl. Sci. 10:2337. doi: 10.3390/app 10072337

Said, S. A. M., Hassan, G., Walwil, H. M., and Al-Aqeeli, N. (2018). The effect of environmental factors and dust accumulation on photo-voltaic modules and dust-accumulation mitigation strategies. Renew. Sust. Energ. Rev. 82, 743-760. doi: 10.1016/j.rser.2017.09.042

Sánchez-Friera, P., Piliougine, M., Peláez, J., Carretero, J., and Cardona, M. S. D. (2011). Analysis of degradation mechanisms of crystalline silicon PV modules after 12 years of operation in Southern Europe. Prog. Photovol.: Res. Appl. 19, 658-666. doi: 10.1002/pip.1083

Sarver, T., Al-Qaraghuli, A., and Kazmerski, L. L. (2013). A comprehensive review of the impact of dust on the use of solar energy: history, investigations, results, literature, and mitigation approaches. Renew. Sust. Energ. Rev. 22, 698-733. doi: 10.1016/j.rser.2012.12.065

Sayyah, A., Horenstein, M. N., and Mazumder, M. K. (2014). Energy yield loss caused by dust deposition on photovoltaic panels. Solar Energy 107, 576-604. doi: 10.1016/j.solener.2014.05.030

Schill, C., Brachmann, S., and Koehl, M. (2015). Impact of soiling on IV-curves and efficiency of PV-modules. Sol. Energ. 112, 259-262. doi: 10.1016/j.solener.2014. 12.003

Suellen, C. S., Antonia Sonia, A. C., and Kazmerski, L. L. (2016). Dust and soiling issues and impacts relating to solar energy systems: literature review update for 2012-2015. Renew. Sust. Energ. Rev. 63, 33-61. doi: 10.1016/j.rser. 2016.04.059

Yan, C., and Yao, W. (2018). Analysis of abnormal power generation and system efficiency of a photovoltaic distributed rooftop power station. Energ. Res. Manag. (chinese) 4, 36-41.

Conflict of Interest: The authors declare that the research was conducted in the absence of any commercial or financial relationships that could be construed as a potential conflict of interest.

Copyright (C) 2021 Cui, Xiao, Xiang and Sun. This is an open-access article distributed under the terms of the Creative Commons Attribution License (CC BY). The use, distribution or reproduction in other forums is permitted, provided the original author(s) and the copyright owner(s) are credited and that the original publication in this journal is cited, in accordance with accepted academic practice. No use, distribution or reproduction is permitted which does not comply with these terms. 